Journal of Agriculture and Food Sciences

Volume 19 Number 1, April 2021 pp 89-109
Jabo, M. S. M., Abubakar, N. A. and

Okebiorun, E. O.

\title{
INCIDENCE, DEPTH AND SEVERITY OF FOOD INSECURITY AMONG FARMING HOUSEHOLDS IN SOKOTO STATE, NIGERIA
}

\author{
Jabo, M. S. M., Abubakar, N. A. and * Okebiorun, E. O. \\ Department of Agricultural Economics, Faculty of Agriculture, Usmanu Danfodiyo \\ University, P.M.B. 2345, Sokoto, Sokoto State, Nigeria \\ *Corresponding Author e-mail: olly74u@yahoo.com
}

\begin{abstract}
The paper examined the incidence, depth and severity of food insecurity among farming household in Sokoto, Nigeria. Data was collected with aid of questionnaire from a total of 440 farming households comprising of (220 beneficiaries and 220 non-beneficiaries of BOA) were randomly selected using four multistage sampling techniques. The data generated was analysed using FGT index. The result for the incidences of food insecurity as indicated by head count ratio shows that $39.55 \%$ and $48.18 \%$ of food insecure farming households beneficiary and nonbeneficiary respectively were not able to meet their recommended daily allowance (RDAs) which is 2,250 kcal valued at N278.40/person equivalent to 0.87 USD. The coefficient of food insecurity depth (gap) shows that 19\% of beneficiary and 44\% of non-beneficiary food insecure farming households are below the recommended daily calorie requirement. The severity of food insecurity shows that 3.6\% of beneficiaries' food insecure farming households are most food insecure in the study area as compared with $19 \%$ non-beneficiaries' food insecure farming households. High incidence, depth and severity of food insecurity among non-beneficiary food insecure farming households, indicated that BOA has impacted on beneficiary farming households by increasing their food security status. Therefore, this study recommends financial policies that ensure financial support to farming households most especially non-beneficiary in the study area.
\end{abstract}

Keywords: Food security, Food insecurity incidence, Food insecurity gap, Beneficiary, Nonbeneficiary.

https://dx.doi.org/10.4314/jafs.v19i1.7

\section{INTRODUCTION}

Bank of Agriculture (BOA) Limited was established on the $24^{\text {th }}$ of March 1973 with primarily aim of agricultural financing at the micro and macro levels as well as micro financing of Small and Medium Scale Enterprises (SMSE). The broad mandate encompasses savings mobilization and the timely delivery of affordable credit to meet the funding requirements of the teeming Nigerian population in the agricultural and non-agricultural sector of the national economy. The objectives of the bank includes: purveyance of affordable credit facilities to the less privileged segment of the society who cannot readily access the services of conventional banks; acceptance of savings deposit from customers and the repayment of same with accrued interest, as and when 
Journal of Agriculture and Food Sciences

Volume 19 Number 1, April 2021 pp 89-109 due; provision of opportunities for self-employment in the rural areas, thereby reducing ruralurban migration; augmentation of Government efforts in the diversification of the productive base of the national economy; inculcation of banking habits at the grass-roots level of the Nigerian society; promotion of capacity building through the provision of relevant training and advisory services; fostering an accelerated growth and development of the agricultural and rural economy and encouraging the formation of co-operative societies at all levels (BOA, 2010).

The right to an adequate standard of living including food security is recognized in the universal declaration of human right. It is a widely accepted fact that food is a basic necessity of life. As such, adequate intake of quality food is a key requirement for a healthy and productive life. Food security is defined as a situation that exists when all people, at all times, have physical, social and economic access to sufficient, safe and nutritious food that meets their dietary needs and food preferences for an active and healthy life (FAO, 2002; World Food Summit, 2003). Food security according to Siamwalla and Valdes (2004) is the ability of the countries, regions or households to meet target levels of food consumption on a yearly basis. The Food and Agricultural Organization (FAO, 2010) also defined food security as a state of affairs where all people at all times have access to safe and nutritious food to maintain a healthy and productive life. Food insecurity exists whenever people are not able to access sufficient food at all times for an active and healthy life (FAO, 2002). It also includes the non-availability of nutritionally adequate and safe foods and the disability to get foods that are socially and culturally acceptable to the society (Life Sciences Research Office, 1990). Similarly, Shala and Stacey (2012) reported that many countries experience food insecurity with food supplies being inadequate to maintain their citizens' per capita consumption. They further reported that Sub-Saharan Africa is the most vulnerable region in terms of food insecurity. It is a dynamic condition and its prevalence may vary by location and time depending on a range of factors (Hamelin et al., 2002).

Studies undertaken in developed countries over the last 14 years have shown the prevalence of food insecurity ranges from four to fourteen percent among samples and up to eighty-two percent among disadvantaged groups, such as ethnic minorities and single parent families (American Dietetic Association, 2006; Chavez and Telleen, 2007). Consequently, various international organizations and individual countries embarked on aggressive food security crusades to remedy the situation in order to make food affordable to all. Asia and Commonwealth of Independent 
Journal of Agriculture and Food Sciences

Volume 19 Number 1, April 2021 pp 89-109
Jabo, M. S. M., Abubakar, N. A. and Okebiorun, E. O. Caribbean countries has varied slightly over time, but there has been a discernible trend across the region as a whole. Despite the strong growth in food production, the challenge according to FAO (2008) is that high food prices will cause increase in food insecurity and widespread food crisis in many developing countries. Poor people in developing countries spend between $50-80 \%$ of their income on food to meet consumers need. Any increase in food prices will reduce food consumption and increase hunger.

The Global Food Security Index considers the core issues of affordability, availability and quality across a set of 113 countries. The index is a dynamic quantitative and qualitative benchmarking model, constructed from 28 unique indicators, that measures these drivers of food security across both developing and developed countries. The Global Food Security Index (GFSI, 2017) of the Economist Intelligence Unit ranked Nigeria as the $92^{\text {th }}$ and score $38.4 \%$ among 113 countries with food affordability, availability and quality. According to the Index, in term of affordability, Nigeria ranked 98 (score 25\%); availability ranked 93 (score 46.4\%); quality and safety ranked 75 (score 59.9\%).

The role of agriculture in the development and growth of the Nigerian economy is primarily indicated in its contribution as a source of food supply. Food security index in Nigeria among the Africa countries, Nigeria ranked $12^{\text {th }}$ and score $37.1 \%$ with the affordability, availability, quality and safety score of 22.8, 45.9 and 48.3 respectively (GFSI, 2017). Food demand in Nigeria has generally grown faster than either food production or total supply (FAO, 2010). Central Bank of Nigeria (2010) reported that the rate of increase in food production of 2.5 percent per annum does not keep pace with the annual population growth rate of 2.8 percent per annum. These are matters of grave concern because Nigeria was self-sufficient in food production and indeed was a net exporter of food to other regions of the continent in the 1950s and 1960s. Despite the huge financial investment in the agricultural sector, many Nigerians cannot afford three square meals a day due to high rate of poverty.

Food security is a concept that has evolved over time, as much literature has spiralled; many definitions and conceptual models on household food security have been presented (Smith et al., 1992). There are approximately 200 definitions and 450 indicators of food security (Hoddinott, 1999). Food security is achieved when all people, at all times, have physical and economic 
Journal of Agriculture and Food Sciences

Volume 19 Number 1, April 2021 pp 89-109

Jabo, M. S. M., Abubakar, N. A. and access to sufficient, safe and nutritious food to meet their dietary needs and food preferences for an active and healthy life' (FAO, 1998). This definition integrates stability, access to food, availability of nutritionally adequate food and the biological utilization of food. The literature is replete with studies on food security especially in developing countries. Babatunde et al. (2007), Clover (2003), Smith (2007), Oriola (2009), Fayeye and Ola (2007) are some of the works that have examined food security in developing countries. The authors argue that domestic policies in many developing countries have contributed very marginally to food security especially in Africa, and that, despite the growing global food production, hunger, malnutrition and famine are prevalent in many developing countries. Oriola (2009) states that Nigeria's case is particularly worrisome owing to the abundant natural resources endowed the country. About $52 \%$ of people in Nigeria live below the poverty line, poverty have remained deeply rooted in Nigeria as about $70 \%$ still live below $\$ 1.25 /$ day (Naisbitt and Naisbitt, 2016). This resulted into high rate of food insecurity among many households.

Several authors have examined the incidence and determinants of both food security and food insecurity in Nigeria (Robert et al., 2013; Eme et al., 2014; Oke, 2015; Ahmed et al., 2015). Few other studies concentrated on poverty and food insecurity in Nigeria (Garba and Sanda, 2007; Lawal and Ayoola, 2008), while some other studies have analysed food security among Nigeria households (Omonona and Agoi, 2007; Arene and Anyaeji, 2010), among other studies on analysis of food security among farming households (Ahmed et al., 2015) and study on incidence, depth and severity of food insecurity among rural household in Nigeria using time series data (Jabo et al., 2014). More specifically, results of studies on the impact of microfinance on food security are mixed. For instance, (Khandker, 1998; Umara et al., 2011; Frank and Agnes, 2013) revealing positive impacts, while others find negative impacts, (Morduch and Aghion, 2000; Weiss and Montgomery, 2005).

Studies have examined food security and related issues; however, most authors have focused on measuring food security using consumption expenditure and suggesting ways of solving food insecurity. Largely missing from previous literature, however, is the link between Bank of Agriculture and food security in the study area. Therefore, this study filled the gap by examining more closely the incidence, depth and severity of food insecurity among beneficiary and non- 
Journal of Agriculture and Food Sciences

Volume 19 Number 1, April 2021 pp 89-109 beneficiary farming households in the selected Local Government Areas of Sokoto States, Nigeria.

\section{MATERIALS AND METHOD}

\section{Study area}

The study was conducted in six Local Government Areas of Sokoto State, Nigeria. The State consists of 23 Local Government Areas (LGAs) and has its capital and seat of government located in Sokoto (Sokoto State Government Diary, 2014). The selected LGAs are Bodinga, Gwadabawa, Silami, Sokoto South, Wamakko and Wurno LGAs. The area is located within Sokoto State which lies between latitudes $12^{0} 42^{\prime} \mathrm{W}-13^{0} 40^{\prime} \mathrm{N}$ and longitudes $4^{0} 37^{\prime} \mathrm{E}-5^{0} 48^{\prime} \mathrm{N}$. It covers a land area of 3,760.44 square kilometres (SOSGD, 2014). The study area falls within the dry Savannah agro ecological zone of Nigeria with an average annual rainfall of between $500 \mathrm{~mm}$ and 1,300mm (SOSGD, 2014). There are two major seasons in the State namely, wet and dry seasons. The dry season starts from October and lasts till April in some parts but may extend to May or June in other parts. The wet season on the other hand, begins in most parts of the State in May and lasts up to September or October. The harmattan, a dry, cold and dusty wind is experienced in the State between November and February. Heat is more severe in the States in March and April but the weather is always cool in the mornings and hot in the afternoon except at the peak of harmattan. The temperature of the area fluctuates; it remains high during the day, but becomes low at night. Mean annual temperature is about $30^{\circ} \mathrm{C}$ with a maximum of $42^{\circ} \mathrm{C}$ in April to May (SOSGD, 2014).

According to the projections from the provisional figures of the 2006 National Population Census (NPC, 2006), the area had a projected population of 1,596,294 million peoples in 2020. Farming constitutes the major occupation of the rural people. Major tree crops grown in the area are mango, pawpaw, guava, banana, citrus, etc. and food crops grown are cassava, potato, pepper, rice, millet, maize, sorghum, guinea corn, wheat, cowpea, groundnut, soybeans, sugarcane, garlic, sesame, etc. Among the livestock raised are cattle, camel, donkey, poultry, cow, sheep, goat, fish horses, etc. Other sources of livelihood in the rural areas are craft making, processing, trading, civil service, hunting, transport and small-scale industrial activities etc. The State is one of the fish producing areas of the country. Thus, a large number of people along the River Basins engage in fishing as well (SMANR, 2013). 
Journal of Agriculture and Food Sciences

Volume 19 Number 1, April 2021 pp 89-109

\section{Sampling Procedure}

The sampling frame for the study consists of the farming households in six selected LGAs of Sokoto State. The sample frame was developed from the list of farming household's beneficiary of Bank of Agriculture in the State, sourced from the BOA and a list of corresponding non beneficiary from extension agents in each LGA. A multi-stage sampling technique was employed for the study. The first stage involved a purposive selection of two agricultural zones: Western zone and Northern zone. The second stage also involved a purposive selection of six LGAs out of 23 LGAs in the State based on the large number of BOA beneficiaries in the areas. The selected LGAs are Bodinga, Gwadabawa, Silami, Sokoto South, Wamakko and Wurno LGAs. The third stage also involved simple random sampling techniques in selecting five villages from each of the LGAs. Last stage involved proportionate selection of farming household heads in each village, sources from the list of farming household's loan beneficiaries obtained from Credit Department of the BOA and a corresponding list of non-beneficiaries farming households obtained from the extension agents from the study area. A total of 440 farming households were sampled (220 farming households each of BOA beneficiaries and nonbeneficiaries).

Data was collected for the study, using a structured questionnaire administered with the help of trained enumerators of the BOA staff and extension agents in the study area. The questionnaire contained information such as the socio-economic characteristics of the respondents (age, sex, marital status, level of education, household size, etc.), and amount of food produced, amount of food purchased, number of foods consumed (quantity of calories consumed etc). The tool used to analyse the data generated from the study was FGT food insecurity index.

\section{Measurement of Variables}

\section{Food Insecurity Index}

In this study, per capital household expenditure was used as a measure of food insecurity incidence and for determining the food insecurity line. The food insecurity index was used to determine the food insecurity levels among the respondents; household whose daily per capita calorie intake is up to $2250 \mathrm{kcal}$ was regarded as food secure and those below were regarded as food insecure. Based on Nanak (2007) recommended $2250 \mathrm{kcal}$ minimum daily threshold for an 
Journal of Agriculture and Food Sciences

Volume 19 Number 1, April 2021 pp89-109 active and healthy life was valued at 0.87 USD equivalents to $\$ 278.40$ (Note $1 \$=\$ 320$ in 2019). Food insecurity index gives a vector of suitable measure of well-being. It is generally given as (Foster et al., 1984; Baffle, 1992):

$$
\mathrm{P}=\frac{1}{N} \sum_{i=1}^{q} \underline{(2}
$$

Where:

$\mathrm{P}=$ Food insecurity index (Foster, Greer and Thorbecke index) $(0 \leq \mathrm{P} \leq 1)$

$\mathrm{N}=$ total number of respondents i.e farming households sampled

$q=$ number of respondents below food insecurity line i.e poor people

$\mathrm{z}=$ the insecurity line

$Y_{i}=$ per capita household expenditure of the $i^{\text {th }}$ respondent.

$\alpha=$ non-negative food insecurity aversion parameter $(0,1$ or 2$)$. The analysis of the food insecurity status of the households were decomposed into the three indicators i.e. incidence of food insecurity $\left(\mathrm{P}_{0}\right)$, insecurity food depth $\left(\mathrm{P}_{1}\right)$ and severity of food insecurity $\left(\mathrm{P}_{2}\right)$.

If $\alpha=0$, the index become $P_{0}=q / n$.

This gives the head count ratio or the incidence of food insecurity which is the percentage of respondents in insecurity i.e whose per capita expenditure is below the food insecurity line.

If $\alpha=1$, it reflects both incidence and depth of food insecurity or the proportion of the food insecurity line that the average poor will require to attain to the food insecurity line.

If $\alpha=2$, the index measures the severity of food insecurity which is the mean of square proportion of the food insecurity gap. When multiplied by 100, it gives the percentage by which a poor household's per capita expenditure should increase to push them out of food insecurity.

\section{Head Count Ratio}

Head count ratio, food insecurity gap, and squared insecurity gap was computed to capture successfully the level of food insecurity among the food insecure farming household following Khatri-Chatri and Maharjan (2006). 
Journal of Agriculture and Food Sciences Volume 19 Number 1, April 2021 pp 89-109

Thus,

$I F I=\times 100$

Where:

$I F I=$ Incidence of food insecurity $(\%)$

$F I H=$ Number of food insecure household

$T H=$ Total household under study

\section{Food Insecurity Gap}

$F I G_{i}=\quad \frac{T C R i}{T C}$

Where:

$F I G_{i}=$ Food insecurity gap of the $\mathrm{i}^{\text {th }}$ food insecure household

$F C R_{i}=$ Total calorie requirement for the $\mathrm{i}^{\text {th }}$ food insecure household

$F C C_{i}=$ Total calorie consumption by $\mathrm{i}^{\text {th }}$ food insecure household

Food insecurity gap: This shows the extent to which individuals fall below food poverty line (Sen, 2009). The main advantage of this poverty measures is that there is no discontinuity in the poverty line. However, its major limitation is that it may not capture the differences in the severity of poverty among food poor.

Therefore, total food insecurity gap is:

$T F I G_{i}=\quad \sum_{i=1}^{n} \frac{T C R i}{T C R i}$

Where:

$T F I G_{i}=$ Total food insecurity gap, which indicates the depth of food insecurity among the food insecure households.

$\mathrm{n}=$ Number of food insecure households. 
Journal of Agriculture and Food Sciences

Volume 19 Number 1, April 2021 pp 89-109

Squared Food Insecurity Gap

$S F I G_{i}=\quad \sum_{i=1}^{n}\left(F^{2} F I H\right.$

Where:

$S F I G_{i}=$ Squared food insecurity gap, which indicates the severity of food insecurity among the food insecure households (ratio).

\section{RESULTS AND DISCUSSION}

\section{Food Insecurity Level}

\section{Food Insecurity Incidence (Head count index)}

Head count describes the percentage of farming households whose per capita income or food consumption is below predetermine subsistence level recommended daily allowances (RDAs). At the farming household level, Table 1 shows the incidence of food insecurity among food insecure beneficiary and non-beneficiary farming households. The incidences of food insecurity as indicated by head count ratio was 39.55 and 48.18 for food insecure beneficiary and nonbeneficiary farming households respectively. This implies that $39.55 \%$ and $48.18 \%$ of food insecure farming households beneficiary and non-beneficiary respectively were not able to meet their recommended daily allowance (RDAs) which is 2,250 kcal valued at N278.40 per person. The result shows that there is higher food insecurity incidence among non-beneficiary farming households when compared to the beneficiary farming households. This result agrees with the finding of Moses (2017) impact of Fadama III project on the poverty status of food farmers in Yobe State where poverty incidence among Fadama III crop farmers was lower than that of non Fadama III crop farmers.

\section{Food Insecurity Depth (Gap)}

The poverty gap ratio is the difference between the poverty line and mean income of the poor, expressed as a ratio of the poverty line (World Bank, 1993). The food insecurity gap index provides an estimate of the average gap between the expenditure of the poor households and the food insecurity line. The coefficient of food insecurity depth (gap) among the beneficiaries and non-beneficiaries' food insecure farming household are presented in the Table 1. The result 
Journal of Agriculture and Food Sciences

Volume 19 Number 1, April 2021 pp 89-109
Jabo, M. S. M., Abubakar, N. A. and

Okebiorun, E. $O$.

shows that, the estimated values of the food insecurity gap are 0.19 and 0.44 for beneficiary and non-beneficiary households respectively. This shows that $19 \%$ of beneficiaries and $44 \%$ of nonbeneficiaries of BOA food insecure farming households are below the recommended daily calorie requirement or are below food insecurity line. On average, a food insecure individual in a particular farming household will require $\mathrm{N} 45.17$ and $\mathrm{N} 82.30$ daily food expenditure for beneficiary and non-beneficiary of BOA respectively to exit food insecurity level.

\section{Food Insecurity Severity}

The food insecurity squared gap index is often described as a measure of the severity of food insecurity among the food insecure households. Food insecurity gap is the distance separating the poor from the food insecurity line. The squared food insecurity gap of the food insecure farming households is presented in Table 2. The result shows that the severity of food insecure indices is 0.036 and 0.19 for beneficiary and non-beneficiary of BOA food insecure farming households respectively. This means that $3.6 \%$ of the beneficiaries' food insecure farming households are most food insecure in the study area as compared with $19 \%$ non-beneficiaries' food insecure farming households.

\section{Food Insecurity Profiles of the Farming Households on some Selected Variable}

Disaggregation of food insecurity status according to selected socio-economic variable of the farming households using the approach adopted by Jabo et al. (2014) on a study examining the incidence, depth and severity of food insecurity among rural households in Nigeria. The approach revealed many interesting findings between the beneficiary and non-beneficiary of BOA micro-finance and the result are presented in the Table 2. The socio-economic variables considered are age, marital status, family size, educational level, and occupation.

\section{Age of the Farming Household Heads and Food Insecurity}

The analysis of the food insecurity situation among the beneficiary and non-beneficiary of BOA farming household in the study area buttressed that beneficiary farming household are more food secure that their counterparts (non-beneficiary farming household). The indices of food insecurity (incidence, depth and severity) for age among food insecure farming households' heads are presented in the Table 2. The food insecurity incidence of age rose from $10 \%$ to $15 \%$ and $16 \%$ to $61 \%$ among beneficiary and non-beneficiaries farming households head respectively 
Journal of Agriculture and Food Sciences

Volume 19 Number 1, April 2021 pp 89-109

Jabo, M. S. M., Abubakar, N. A. and Okebiorun, E. O.

for those that are between the age of 20 years and below ( $\leq 20$ years) and 21 to 40 years. The higher incidence occurs (48\%) among beneficiaries farming household heads that are within the ages of 41 to 60 years. This is in line with the finding of Idrisa et al. (2008) stated that, incidence of food insecurity was found to be higher among households within the age bracket $(40-49)$ years. The result also shows that there are decreases in incidence as the age increases among the beneficiaries and non-beneficiaries farming household heads in the study area

The depth of food insecurity decreases from $\propto=1(0.36)$ to $(0.18)$ and $\propto=1(0.63)$ to (0.07) for farming household heads between the age of 20 years and below among the beneficiaries and non-beneficiaries' food insecure farming household respectively. On the other hand, the severity of food insecurity also decreases with increase in age of the farming household heads from $\propto=2$ (0.13) to (0.032) and $\propto=2(0.40)$ to (0.0049) for household heads between the ages of 20 years and below $(\geq 20)$ and above 60 years $(>60)$ among beneficiaries and non- beneficiaries farming household respectively. This implies that non-beneficiary household has more incidence, depth and severity of food insecurity than their counterpart beneficiary farming household. The decreases in food insecurity (incidence, depth and severity) among farming household heads above 60 years of age may be due to additional income from their grown up economically active adult members of the households. This finding is in line with life cycle hypothesis assumption that older households have a probability of being food secure (Jabo et al., 2014).

\section{Marital Status and Food Insecurity}

The food insecurity indices base on marital status of farming household heads among beneficiaries and non- beneficiaries of BOA are presented in Table 2. The distribution shows those households headed by married man are most food insecure among the beneficiaries and non-beneficiaries farming household. The indices among beneficiary married farming household heads reveals the incidence (72\%), depth (0.20) and severity (0.04) and indices among nonbeneficiary married farming household heads reveals the incidence $(70 \%)$, depth $(0.35)$ and severity (0.12). The least food insecurity indices (incidence $=28 \%$, depth $=0.13$ and severity $=$ 0.017) are reported among the single headed beneficiary farming household. But among single headed non-beneficiary farming household, food insecurity incidence is $30 \%$, depth (0.65) and severity (0.42). This implies that married farming household head among both the beneficiaries and non-beneficiaries farming household have highest indices of food insecurity as a result of 
Journal of Agriculture and Food Sciences

Volume 19 Number 1, April 2021 pp 89-109

Jabo, M. S. M., Abubakar, N. A. and large household size. This is in agreement with Jabo et al. (2014) who stated that, the high food insecurity among the married households as compared to unmarried households could be attributed to larger household size and high dependency ratio for married households. Abimbola and Kayode (2013) also revealed that households with married head were more food insecure than those with single head.

\section{Household Size and Food Insecurity}

Distribution of farming households by household size reveals that, the incidence, depth and severity of food insecurity increases with increase in the household size among beneficiary farming household (Table 2). The incidence, depth and severity increase with increase in household size from $(3 \%, 0.018$ and 0.00032$)$ to $(42 \%, 0.27$ and 0.073$)$ for beneficiary farming household with 5 and below household sizes and above 20 household sizes respectively. Among the non-beneficiary farming households, incidence, depth and severity of food security also increases with increase in the household size. The incidence, depth and severity of food insecurity increases from $(2.5 \%, 0.30$ and 0.09$)$ to $(41 \%, 0.72$ and 0.52$)$ for non-beneficiary farming households with 5 and below household sizes and 21 and above household sizes respectively. This means an increase in household size led to an increase in food insecurity among the both beneficiaries and non-beneficiaries farming household in the study area. The household size has been shown to have a negative relationship with food security and food intake (Amaza et al., 2008). The result is in line with the findings of Olayemi (1998) and Obamiro et al. (2003) who reported that larger household sizes increased the probability of becoming food insecure.

\section{Education Level of Farming Household Heads and Food Insecurity}

Education of the farming households' heads are expected to have positive impact on the food security status of the entire households. Assessment of education in Table 2 reveals those households headed with Islamic education have the highest food insecurity status. The incidence, depth and severity are $(48 \%, 0.20$ and 0.04$)$ for beneficiary farming household heads and (35\%, 0.52 and 0.27 ) for non-beneficiary farming household heads. The food insecurity situation among the farming household head with tertiary education are better than farming household head with primary, secondary and Islamic education. The result recoded low incidence, depth 
Journal of Agriculture and Food Sciences

Volume 19 Number 1, April 2021 pp 89-109

Jabo, M. S. M., Abubakar, N. A. and and severity of (10\%, 0.018 and 0.00032$)$ and $14 \%, 0.38$ and 0.14$)$ among the beneficiaries and non-beneficiaries respectively.

This implies that education as a social capital impact positively to the farming household ability to take good and well-informed production and nutrition decision and increases food security by improving household food accessibility (Goni, 2011; Jabo et al., 2014). In the same view Abimbola and Kayode (2013) also revealed that households whose heads had tertiary education had the lowest incidence and depth of food insecurity

\section{Occupation of the Farming Household Head and Food Insecurity}

Occupation distributions of farming household are presented in Table 2. The Table shows that farming household whose primary occupation is farming only has highest incidence, depth and severity of food insecurity $(73 \%, 0.16$ and 0.026$)$ and $(78 \%, 0.46$ and 0.21$)$ for beneficiary and non-beneficiary farming household respectively. The highest indices of food insecurity among non-beneficiary farming household when compared with beneficiary farming household shows that non-beneficiary farming household are more food insecure than beneficiary farming household. However, incidence, depth and severity of food insecurity are less among the farming household whose primary occupation is not farming, the indices are $(27 \%, 0.12$ and 0.014$)$ and $(22 \%, 0.37$ and 0.14$)$ for beneficiary and non-beneficiary farming household respectively.

This implies that household with multiple incomes generating activities besides farming are likely to be food secure than those that rely on farming as their only source of income. This is in agreement with Asogwa and Umeh (2012) who found that households with relatively more diverse sources of farm income tended to have a lower probability of being poor than those with relatively less diverse enterprises and income sources. The result also consonance with the findings of Olarinde and Kuponiyi (2005) in which households that spent more on non-food items was less likely to be food insecure. Whereas, Oseni and Winters (2009) showed that offfarm activities in Nigeria help households to improve their farm production through the use of quality inputs, including more employment of labour. 

CONCLUSION

The differences in food insecurity exist among the BOA beneficiary and non-beneficiary food insecure farming households as well as other socio-economic characteristics of the farming households in the study area. Determinant of incidence, depth and severity of food insecurity among food insecure farming households revealed that, incidence of food insecurity as indicated by head count ratio are less among beneficiary than non-beneficiary food insecure farming households. The severity of food insecurity also shows that beneficiaries' food insecure farming households are most food insecure in the study area when compared with non-beneficiaries' food insecure farming households. Low incidence, depth and severity of food insecurity among beneficiary of BOA food insecure farming households, indicated that BOA has positively impacted on beneficiary farming households by increasing their food security status. It is therefore recommended that BOA should increases the number of beneficiaries so that nonbeneficiary farming households will be encouraged to access loan and their food security status will as well increase. 
Journal of Agriculture and Food Sciences

Volume 19 Number 1, April 2021 pp 89-109

Jabo, M. S. M., Abubakar, N. A. and Okebiorun, E. O.

\section{REFERENCES}

Abimbola, O. A. \& Kayode, A. A. (2013). Food Insecurity Status of Rural Households during the Post-planting Season in Nigeria. Journal of Agriculture and Sustainability, 4(1), 16-35.

Ahmed, F. F., Eugene, C. E. \& Abah, P. O. (2015). Analysis of Food Security among Farming Households in Borno State, Nigeria. Journal of Agricultural Economics, Environment and Social Sciences, 1(1), 130-141.

Amaza, P. S., Adejobi, A. O. \& Fregene, T. (2008). Measurement and Determinants of Food Insecurity in Northeast Nigeria: Some Empirical Policy Guidelines. Journal of Food, Agricultural and Environment, 6(2), 92-96.

American Dietetic Association (2006). Position of the American Dietetic Association: Food Insecurity and Hunger in the United States. Journal of the American Dietetic Association, 106(3), 446-458. https://doi.org/10.1016/j.jada.2006.01.016

Arene, C. J. \& Anyaeji, R. C. (2010). Determinants of Food Security among Households in Nsukka Metropolis of Enugu State, Nigeria. Pakistan Journal of Social Science (PJSS), 30(1), 9-16.

Asogwa, C. J. \& Umeth, M. R. (2012). Food Insecurity Determinants among Rural Farm Households in Nigeria. In ICEACS (Ed.), International Conference on Ecology, Agriculture and Chemical Engineering (ICEACS'2012) December 18-19, 2012 Phuket (Thailand) (pp. 206-211).

Babatunde, R. O, Omotesho, O. A, \& Sholotan, O. S. (2007). Socio-Economics Characteristics and Food Security Status of Farming Households in Kwara State, North-Central Nigeria. Pakistan Journal of Nutrition, 6(1), 49-58. https://doi.org/10.3923/pjn.2007.49.58

Baffoe, J. K. (1992). Income Distribution and Poverty Profile in Ghana 1987 - 1988. In: African Development Review, 4(1), 1-28. https://doi.org/10.1111/j.1467-8268.1992.tb00146.x

Bank of Agriculture Limited (2010). Brochure, Customers Guide. A Publication of the Corporate Affairs Division, NACB Sokoto.

Central Bank of Nigeria (CBN) (2010). Economic and Financial Review, 36(1), 8-12.

Chavez, N. \& Telleen, S. (2007). Food Insufficiency in Urban Latino Families. Journal of Immigrant Minority Health, 9, 197 - 204. https://doi.org/10.1007/s10903-006-9032-8

Clover, J. (2003). Food Security in Sub-Saharan Africa. African Security Review, 12(1), 5-15. https://doi.org/10.1080/10246029.2003.9627566 
Journal of Agriculture and Food Sciences

Volume 19 Number 1, April 2021 pp 89-109

Jabo, M. S. M., Abubakar, N. A. and

Okebiorun, E. O.

Ekpa, D., Oyekale, A. S. \& Oladele, O. I. (2017). Evaluation of Factors Influencing Indicators of

Climate Smart Agricultural Practice on Crop in North-West Nigeria. World Journal of Agricultural Research, 5(5), 273 - 278. DOI:10.12691/wjar-5-5-4.

Eme, O., Onyishi, T., Uche, O. \& Uche, I. (2014). Challenges of Food Security in Nigeria:

Options before Government, Arabian Journal of Business and Management Review, 4(1),

15-25. https://doi.org/10.12816/0016564

Fayeye, T.R \& Ola, D.J. (2007). Strategies for Food Security and Health Improvement in the

Sub-Saharan Africa. World Journal of Agricultural Sciences, 3(6), 808-814.

Food and Agricultural Organization. (1998). Food and Agricultural Organization.Africa Agriculture. The next 25 years. Rome, Italy: FAO.

Food and Agricultural Organisation. (2002). Household Food Security in Mounting Areas an often Fogotten Story. Food and Nutrition Division Economic and Social Department Food and Agricultural Organization of the United Nations Viale delle Terme di Caracalla - 00100 Rome, Italy. p 17.

Food and Agricultural Organization. (2008). Global Food Security: Issues and Prospects. Rome: Italy.

Food and Agricultural Organization. (2010). The State of Insecurity in the World: Addressing Food Insecurity in Protracted Crisis. Rome, Italy.

Foster, J., Greer J. \& Thorbecke, E. (1984). A Class of Decomposable Poverty Measures. Econometric. 52, 761-765. https://doi.org/10.2307/1913475

Frank, G. \& Agnes, E. G. M. (2013). Impact of Microfinance on Smallholder Farm Productivity in Tanzania: The Case of Iramba District. Asian Economic and Financial Review, 3(2), 227242.

Garba, T. \& Sanda, A. U. (2007). Rural Household Poverty and Child Work: A Test of Luxury Axiom and Wealth Paradox in Rural Sokoto State of Nigeria. Maiduguri Journal of Art and Social Sciences, 5(2), 135-153

Global Food Security Index (2017). The State of Food Insecurity in the World. http://foodsecurityindex.eiu.com/

Goni, M. (2011). Household Food Security Situation, Determinants and Coping Strategies in Borno State, Nigeria. Unpublished PhD Thesis Submitted to Department of Agricultural Economics and Extension, Usmanu Danfodiyo University, Sokoto State, Nigeria. 
Journal of Agriculture and Food Sciences

Volume 19 Number 1, April 2021 pp $89-109$

Hamelin, A. M., Beaudry, M. \& Habicht, J. P. (2002). Characterization of Household Food

Insecurity in Quebec: Food and Feelings. Social Science and Medicine, 54, 119 - 132. https://doi.org/10.1016/S0277-9536(01)00013-2

Hoddinott, J. (1999). Choosing Outcome Indicators of Household Food Security. Washington DC: IFPRI.

Idrisa, Y. L., Gwary, M. M. \& Shehu, H. (2008). Analysis of Food Security Status among Farming Household in Jere Local Government Area of Borno State, Nigeria. Jounal of Trop Agric Food Envirn Ext, 7(3), 199-205. https://doi.org/10.4314/as.v7i3.45552

Jabo, M. S. M., Ismail, M. M., Shamsuddin, M. N., Abdullah, A. M. \& Maikasuwa, A. M. (2014). Examining the Incidence, Depth and Severity of Food Insecurity among rural Households in Nigeria. Journal of Economics and Sustainable Development. 5(26), 32 - 42.

Khandker, S. R. (1998). Fighting poverty with microcredit: Experience from Bangladesh. New York: Oxford University Press.

Khatri-Chatri, A \& Maharjan, K. L. (2006). Food security and coping strategies inrural areas of

Nepal: A case of Dailekh District in Mid-Western Development Region. Journal of International Development and Cooperation, 12(2), 25-45.

Lawal, B. O. \& Ayoola, O. T. (2008). Farmers Knowledge and Use of Pacesetters Organic Fertilizer for Arable Crops in Oyo State, Nigeria. Nigerian Journal of Agriculture and Rural Development, 2, 55-68.

Life Sciences Research Office. (1990). Core Indicators of Nutritional Status for Difficult-toSample Population. Journal of Nutrition, 120, 1559 - 1600. https://doi.org/10.1093/jn/120.suppl_11.1555

Morduch, J. \& Aghion, A. B. (2000). Microfinance beyond group lending. Economi. Transition, 8(2), 401 - 420. https://doi.org/10.1111/1468-0351.00049

Moses, J. D. (2017). The Impact of Fadama III on the Poverty Status of Food Crop Farmers in Yobe State, Nigeria. Sky Journal of Agricultural Research. 6(4), 78 - 84.

Naisbitt, J. \& Naisbitt, D. (2016). Global Game Change: How the Global Southern Belt Will Reshape our World. Sage Publications, New Delhi

Nanak, K. (2007). New Global Poverty Counts. Asian Development Review, 24(2), 17-36 
Journal of Agriculture and Food Sciences

Volume 19 Number 1, April 2021 pp 89-109

Nigerian Population Census. (2006). Official Gazatte (FGP 71/52007/2,500(OL24): Legal totals 2006 census. Retrieved from http://www.nigerianstate.gov.ng.

Obamiro, E. O, Doppler, A. \& Kormawa, P. M. (2003). Pillars of Food Security in Rural Areas of Nigeria. Food Africa, Internet Forum Paper accepted for the Food Security Theme. Available onlinehttp://foodafrica.nri.org/security/internetpapers/ObamiroEunice.

Olarinde L. O. \& Kuponiyi, F. A. (2005): Rural livelihood and food consumption patterns amonghouseholds in Oyo State, Nigeria: Implications for food security and poverty eradication in aderegulated economy. Journal of Social Science, 11(2), 127 - 132. https://doi.org/10.1080/09718923.2005.11892504

Olayemi, J. K. (1998). Food Security in Nigeria, Development Policy Center. Policy Report, Ibadan. No. 2, p 154.

Oke, M. A. (2015). Determinants of National Food Security in Nigeria. Journal of Economics and Sustainable Development, 6(9), 100 - 107.

Omonona, B. T. \& Agoi, G. A. (2007). An Analysis of Food Security among Nigeria Urban Households: Evidence from Lagos, Nigeria. Journal of Central European Agriculture, 8(3), $397-406$.

Omonona, T., Adetokunbo, G. \& Titus, B. (2007). An Analysis of Food Security Situation Among Nigerian Urban Households: Evidence from Lagos, Nigeria. Journal of Central European Agriculture, 8(2), 397 - 406.

Oriola, E. O. (2009). A Framework for Food Security and Poverty Reduction in Nigeria. European Journal of Social Sciences, 8(1), 132 - 139.

Oseni, G. \& Winters, P. (2009). Rural Non-farm Activities and Agricultural Crop Production in Nigeria. Agricultural EconomicsJournal, 40(2), 189 - 201. https://doi.org/10.1111/j.15740862.2009.00369.x

Robert, A., James, O. M. \& Thomas, T. (2013). Determinants of Household Food Security in the Sekyere-Aframplains District of Ghana 1st Annual International Interdisciplinary Conference, AIIC- proceedings- Azores, Portugal. P 24-26.

Sen, A. (2009). Measurement and Determinants of Poverty - Application of Logistic Regression Models. 
Journal of Agriculture and Food Sciences

Volume 19 Number 1, April 2021 pp 89-109

Jabo, M. S. M., Abubakar, N. A. and

Shala, A. \& Stacey, E. (2012). United States Department of Agriculture: Economic Research Service. Food Security Assessment, Regional Overview Information Bulleti.

Siamwalla, A. \& Valdes, A. (2004), Global Food Policy and Food Security Crisis, IFPRI. Washington D. C.

Smith, J. (2007). Food Security in Sudan. Darfur-Overview. Sudan. June 2007. UNICEF. http://www.unicef.org/infobycountry/sudan_darfuroverview.html

Smith, M., Pointing, J. \& Maxwell, S. (1992). Household Food Security, Concepts and Definitions: AnAnnotated Bibliography. Development Bibliography No. 8. Institute of Development Studies (IDS), Brighton.

Sokoto State Government Diary. (2014). Yearly Publication by Home Affairs Department, Sokoto State, $\mathrm{p} 302$.

State Ministry of Agriculture and Natural Resources. (2013). State Ministry of Agriculture and Natural Resources Annual Report, Sokoto State, Nigeria, p 56.

Umara, N., Rabia, I., Arshad, Z. \& Iqbal Saif, M. (2011). Impact of Microfinance on Poverty: A Case of Pakistan. World Applied Sciences Journal, 12(6), 877 - 883.

Weiss, J. \& Montgomery, H. (2005). Great expectations: Microfinance and poverty reduction in Asia and Latin America. Oxford Development Studies, 33(3 - 4), 391 - 416. https://doi.org/10.1080/13600810500199210

World Bank. (1993). Poverty Reduction Hand book. The World Bank, Washington D. C. World Food Summit. (1996). Agriculture and Sustainable Development, Rome: FAO. 
Journal of Agriculture and Food Sciences Volume 19 Number 1, April 2021 pp 89-109

\section{APPENDICES}

Table 1: Incidence, Depth and Severity of Food Insecurity among Farming Household

\begin{tabular}{lccccc}
\hline \multicolumn{1}{c}{ Variable } & \multicolumn{2}{c}{ Beneficiaries } & \multicolumn{2}{c}{ Non-beneficiaries } \\
Farming households size & & 220 & 100 & 220 & 100 \\
Food secure households & & 133 & 60.4 & 114 & 51.82 \\
Food insecure households & & 87 & 39.55 & 106 & 48.18 \\
Incidence & $\propto=0$ & 39.55 & & 48.18 & \\
Depth & $\propto=1$ & 0.19 & & 0.44 & \\
Severity & $\propto=2$ & 0.036 & & 0.19 & \\
\hline
\end{tabular}

Source: Researcher's Calculation, 2020. 
Journal of Agriculture and Food Sciences

Volume 19 Number 1, April 2021 pp 89-109

Jabo, M. S. M., Abubakar, N. A. and Okebiorun, E. O.

Table 2: Food Insecurity Profiles of the Farming Households on some Selected Variables

\begin{tabular}{|c|c|c|c|c|c|c|}
\hline \multirow[b]{2}{*}{ Variable } & \multicolumn{2}{|c|}{ Beneficiary } & \multirow[b]{2}{*}{$\begin{array}{c}\text { Severity } \\
=2\end{array}$} & \multicolumn{3}{|c|}{ Non-beneficiary } \\
\hline & $\begin{array}{l}\text { Incidence } \\
\quad=0\end{array}$ & $\begin{array}{c}\text { Depth } \\
=1\end{array}$ & & $\begin{array}{l}\text { Incidence } \\
=0\end{array}$ & $\begin{array}{l}\text { e Depth } \\
=1\end{array}$ & $\begin{array}{l}\text { Severity } \\
=2\end{array}$ \\
\hline \multicolumn{7}{|l|}{ Age (Years) } \\
\hline$\leq 20$ & 0.10 & 0.36 & 0.13 & 0.16 & 0.63 & 0.40 \\
\hline $21-40$ & 0.15 & 0.32 & 0.10 & 0.61 & 0.47 & 0.22 \\
\hline $41-60$ & 0.48 & 0.20 & 0.04 & 0.22 & 0.27 & 0.073 \\
\hline$>60$ & 0.27 & 0.18 & 0.032 & 0.13 & 0.07 & 0.0049 \\
\hline \multicolumn{7}{|l|}{ Marital Status } \\
\hline Single & 0.09 & 0.13 & 0.017 & 0.30 & 0.65 & 0.42 \\
\hline Married & 1.91 & 0.20 & 0.04 & 0.70 & 0.35 & 0.12 \\
\hline \multicolumn{7}{|c|}{ Household Size (Numbers) } \\
\hline$\leq 5$ & 0.03 & 0.018 & 0.00032 & 0.025 & 0.30 & 0.09 \\
\hline $6-10$ & 0.10 & 0.023 & 0.00053 & 0.13 & 0.37 & 0.14 \\
\hline $11-15$ & 0.27 & 0.039 & 0.0015 & 0.15 & 0.38 & 0.14 \\
\hline $16-20$ & 0.18 & 0.17 & 0.029 & 0.29 & 0.57 & 0.32 \\
\hline$>20$ & 0.42 & 0.27 & 0.073 & 0.41 & 0.72 & 0.52 \\
\hline \multicolumn{7}{|c|}{ Educational Level } \\
\hline Islamic & 0.46 & 0.20 & 0.040 & 0.35 & 0.52 & 0.27 \\
\hline Primary & 0.25 & 0.18 & 0.032 & 0.33 & 0.50 & 0.25 \\
\hline Secondary & 0.19 & 0.056 & 0.0031 & 0.18 & 0.45 & 0.20 \\
\hline Tertiary & 0.10 & 0.18 & 0.00032 & 0.14 & 0.38 & 0.14 \\
\hline \multicolumn{7}{|l|}{ Occupation } \\
\hline Farming only & 0.73 & 0.16 & 0.026 & 0.78 & 0.46 & 0.21 \\
\hline Non farming & 0.27 & 0.12 & 0.014 & 0.22 & 0.37 & 0.14 \\
\hline
\end{tabular}

Source: Researcher's calculation, 2020 